\title{
Sebuah Kajian Historis: Periodesasi Dan Tartib Mushafi Ayat-Ayat Al-Quran
}

\author{
Abdul Majid \\ Magister Ilmu Syari'ah \\ Universitas Islam Negeri Sunan Kalijaga Yogyakarta \\ Email: Jiddoank.1987@gmail.com \\ Arif Sugitanata \\ Magister Ilmu Syari'ah \\ Universitas Islam Negeri Sunan Kalijaga Yogyakarta \\ Email: arifsugitanata@gmail.com
}

\begin{abstract}
.
The existence of the Koran cannot be separated from the history of the beginning of revelation, this shows that the Koran came back and the reason for that verse was revealed, because the Koran is an eternal and appreciative miracle that comes out of its relevance in facing all changes. Al-Quran is the holy book contained in the main teachings for human life, both from the perspective of economy, education, government, health and so on. These instructions are the basis for adherents to always hold fast in carrying out all activities for the happiness of life in this world and in the hereafter. This paper tries to review the period of Makkiyah and Madaniyah and explains the tartib which is the basis for the compilation of the Koran, so that it can be seen that the purpose of the Qur'anic verse which was passed down gradually was to provide for its adherents and as a differentiator from books that also the arrangement of verses and letters in the Koran is more tauqifi based on the Prophet's instructions in accordance with Allah's revelation because the Koran is a miracle of the Prophet Muhammad which contains universal values and is interrelated as a whole in one unity.
\end{abstract}

Keywords: Periodesasi, Tartib, Mushaf, Al-Qur'an.

\section{Abstrak.}

Keberadaan al-Quran tidak bisa terlepas dari sejarah awal mula turunnya wahyu, hal ini menunjukkan bahwa al-Quran turun mempunyai latar belakang dan penyebab ayat itu diturunkan, karena al-Quran adalah mu'jizat abadi dan apresiatif yang diperkuat dengan kerelevansiannya dalam menghadapi segala perubahan. Al-Quran adalah kitab suci yang terkandung di dalamnya ajaran pokok bagi kehidupan manusia, baik dari segi ekonomi, pendidikan, pemerintahan, kesehatan dan lain sebagainya. Petunjuk inilah yang menjadi landasan bagi pemeluknya untuk selalu berpegang teguh dalam menjalankan segala aktivitas demi kebahagiaan kehidupan di dunia maupun di akhirat. Tulisan ini mencoba mengupas kembali periodesasi Makkiyah dan Madaniyah serta menjelaskan tartib yang menjadi dasar dalam penyusunan al-Quran, sehingga dapat diketahui bahwa tujuan ayat al-Quran diturunkan secara berangsurangsur adalah agar dapat memberikan pengajaran bagi pemeluknya dan sebagai pembeda dari kitab-kitab yang diturunkan sebelumnya, begitu juga susunan ayat dan surat dalam al-Quran lebih bersifat tauqifi berdasarkan petunjuk Nabi sesuai dengan wahyu Allah karena al-Quran sebagai mu'jizat Nabi Muhammad yang memiliki kandungan nilai universal dan saling terkait secara utuh dalam satu kesatuan.

Kata Kunci: Periodesasi, Tartib, Mushaf, Al-Qur'an.

\section{PENDAHULUAN}

Dalam pandangan umat Islam, al-Quran merupakan wahyu Allah yang diturunkan kepada Nabi Muhammad melalui malaikat Jibril sebagai aturan dan pedoman yang bertujuan untuk membimbing manusia pada jalan kebenaran. Al-Quran 
adalah kitab suci yang terkandung di dalamnya ajaran pokok bagi kehidupan manusia, baik dari segi ekonomi, pendidikan, pemerintahan, kesehatan dan lain sebagainya. Petunjuk inilah yang menjadi landasan bagi pemeluknya untuk selalu berpegang teguh dalam menjalankan segala aktivitas demi kebahagiaan kehidupan di dunia maupun di akhirat. ${ }^{1}$ Al-Quran merupakan mu'jizat abadi dan apresiatif yang diperkuat dengan kerelevansiannya dalam menghadapi perubahan zaman dan perekembangan ilmu pengetahuan. Hal ini menunjukkan bahwa al-Quran merupakan kitab suci yang diturunkan Allah kepada Nabi Muhammad secara konteks selalu mengiringi perjalanan hidup manusia dan sangat relevan dengan kehidupan yang semakin modern ini.

Di era yang semakin komplek, perlu adanya kajian ulang tentang periodesasi alQuran dalam kurun waktu masa Nabi, masa sahabat dan masa pengkodifikasiannya. Tulisan ini berusaha menjelaskan sejarah turunnya wahyu al-Quran yang menyangkut periode Makkiyah dan Madaniyah. Dari pembahasan periodesasi turunnya wahyu ini kemudian diharapkan dapat memahami tartib mushafi ayat-ayat dan surat-surat dalam al-Quran, karena mempelajari asbabun nuzul dan tartib mushafi adalah kunci utama untuk mengetahui isi kandungan al-Quran secara baik dan benar, terutama ayat-ayat yang menyangkut masalah hukum, karena al-Quran diturunkan berinteraksi langsung dengan keadaan masyarakat dalam konteks sejarah dan sosiologis. ${ }^{2}$

Kajian ini menggunakan studi kepustakaan karena bahan dan data dalam penyusunannya menggunakan kitab suci Al Qur'an, buku-buku dan jurnal yang berhubungan dengan Sebuah Kajian Historis: Periodesasi Dan Tartib Mushafi AyatAyat Al-Quran. Selanjutnya data yang digunakan dalam kajian ini ialah kajian kualitatif dengan sifat penelitian yang digunakan adalah deskriptif analitis.

\section{POTRET PERIODESASI MAKKIYAH DAN MADANIYAH}

Dalam proses turunnya al-Quran kepada Nabi Muhammad para ulama berbeda pandangan, sebagaimana As-suyuti dalam kitab Al-Itqa membagi menjadi tiga:

\footnotetext{
${ }^{1}$ Cahaya Khaeroni, Sejarah Al-quran (Uraian Analitis, Kronologis, dan Naratif tentang Sejarah Kodifikasi Al-4XU.DQ), Jurnal Historia, Volume 5, Nomor 2, (Tahun 2017), hlm. 193.

${ }^{2}$ Usman, Ulumul Quran, cet. ke-1, (Yogyakarta: Sukses Offset), hlm. 137-138.
} 
Pertama, Allah menurunkan al-Quran dari lauh al-mahfuz ke langit dunia secara sekaligus pada lailat al-qadr, kemudian Allah mewahyukan al-Quran melalui perantara Jibril kepada Nabi Muhammad secara berangsur-angsur. ${ }^{3}$ Kedua, Allah menurunkan alQuran pada lailat- al-qadr kemudian diwahyukan secara berangsur-angsur kepada Nabi Muhammad tanpa melalui transit ke langit dunia. Ketiga, Allah menurunkan al-Quran dari lauh al-mahfuz ke langit dunia selama dua puluh tiga kali setiap lailat al-qadr kemudian diwahyukan kepada Nabi Muhammad secara berangsur-angsur. Dari perbedaan ini, maka pendapat yang paling kuat adalah bahwa Allah menurunkan alQuran secara langsung pada lailat al-qadr sebagai khabar kepada penghuni alam samawi tentang kemuliaan dan kebesaran Nabi Muhammad SAW, kemudian Allah menurunkannya secara bertahap. Tujuannya adalah sebagai pembeda dari kitab-kitab yang diturunkan sebelumnya, untuk menghibur dan menguatkan hati Nabi Muhammad SAW sesuai dengan pertanyaan dan peristiwa yang mengitarinya ${ }^{4}$ sekaligus cara yang bijaksana untuk membimbing dan menuntun masyarakat ketika itu keluar dari kebodohan dan krisis moral, karena awal mula al-Quran turun adalah untuk mengajarkan akhlak mulia serta menjelaskan landasan halal dan haram sebagai dasardasar keimanan. ${ }^{5}$

Masa turunnya wahyu Allah ini berlangsung selama 23 tahun yang dibagi menjadi dua periode, pertama yakni periode Makkah dalam kurun waktu 13 tahun dan kedua periode Madinah dalam kurun waktu 10 tahun. Wahyu Allah yang diturunkan sebelum Nabi Muhammad hijrah, dinamakan surat atau ayat Makkiyah. Wahyu Allah yang diturunkan setelah Nabi Muhammad hijrah, dinamakan surat atau ayat Madaniyah. Untuk menentukan surat atau ayat Makkiyah dan Madaniyah dilakukan dengan cara qiyasi ijtihadi, apabila dalam surat Makkiyah ada ayat yang mengandung sifat Madani, maka dikelompokkan ke ayat Madaniyah, apabila dalam surat Madaniyah terdapat ayat

\footnotetext{
${ }^{3}$ Abdur Rahman bin Abi Bakar Al-Suyuti, Al-Itqan Fi 'Ulum Al-Qur'an, (Beirut: Dar al-Kutub al-'Ilmiyyah, 2004), hlm. 19.

${ }^{4}$ H. Ainur Rafiq El-Mazni, Pengantar Studi Ilmu Al-quran, cet. ke-2, (Jakarta: Pustaka AlKausar), hlm. 124. Terjemahan dari Manna Al-qaththan, Mabahis fi Ulumil Quran, cet. ke-13, (Kairo: Maktabah Wahbah).

${ }^{5}$ Muhammad Amin, Sistematika Turunnya Ayat-ayat Al-quran Sebagai Pola Gerakan Dakwah, Communica, Vol 2, No. 02, (Oktober 2004), hlm. 85.
} 
yang mengandung sifat Makki, maka dikelompokkan ke ayat Makkiyah. ${ }^{6}$ Para ulama sepakat, setiap surat yang mengandung kisah para Nabi dan umat terdahulu, maka surat tersebut tergolong Makkiyah dan setiap surat yang mengandung kewajiban atau ketentuan hukum, maka surat tersebut tergolong Madaniyah.

\section{Periode turunnya wahyu al-Quran}

a. Periode pertama turunnya wahyu kurang lebih selama empat sampai lima tahun di Makkah. Wahyu pertama turun adalah iqra' dan Nabi belum dilantik menjadi Rasul yang tidak ditugaskan untuk menyampaikan apa yang diterima. Wahyu kedua turun adalah "Wahai orang yang berselimut, bangkit dan berilah peringatan", 7 dengan turunnya wahyu yang kedua inilah Nabi ditugaskan untuk menyampaikan apa yang diterima. wahyu ketiga turun adalah "Wahai orang yang berselimut, bangun dan shalatlah di seperdua malam serta bacalah al-Quran dengan berlahan-lahan". 8 Wahyu Allah turun dengan tahap ini mengandung arti:

b. Pendidikan bagi Nabi untuk membentuk kepribadiannya, dengan firman Allah yang berbunyi: "Wahai orang yang berselimut, bangun dan sampaikanlah. Agungkanlah nama Tuhanmu. Bersihkanlah pakaianmu. Tinggalkanlah perbuatan syirik. Ketika memberi sesuatu janganlah mengharap lebih dan bersabarlah dalam melaksanakan perintah Tuhanmu.9 Perintah ini disebabkan karena kami akan menurunkan wahyu yang sangat berat kepadamu".10 Sebagaimana juga firman Allah yang berbunyi: "Berilah peringatan kepada keluarga terdekatmu, rendahkanlah hatimu, janganlah berlaku sombong kepada orang-orang beriman yang mengikutimu. Jika keluargamu tidak mau mengikuti, katakanlah: aku berlepas dari apa yang kalian kerjakan". ${ }^{11}$

${ }^{6}$ H. Ainur Rafiq El-Mazni, Pengantar Studi Ilmu Al-quran, cet. ke-2, (Jakarta: Pustaka AlKausar), hlm. 72-73. Terjemahan dari Manna Al-qaththan, Mabahis fi Ulumil Quran, cet. ke-13, (Kairo: Maktabah Wahbah).

${ }^{7}$ QS. Al-Mudatshir ayat 1-2.

${ }^{8}$ QS. Al-Muzammil ayat 1-4.

${ }^{9}$ QS. Al-Mudatshir ayat 1-7.

${ }^{10}$ QS. Al-Muzammil ayat 5.

${ }^{11}$ QS. Ash-Shu'ara ayat 214-216. 
c. Pengetahuan dasar tentang sifat Allah, sebagaimana surat al-Alaq dan surat al-Ikhlas yang sebanding dengan sepertiga al-Quran, karena surat tersebut menjelaskan tentang tauhid dan tanzih (penyucian Allah).

d. Keterangan tentang dasar akhlak mulia serta bantahan terhadap pandangan hidup orang-orang Jahiliyah. Sebagaimana surat al-Takatsur mengecam orang-orang Jahiliyah yang menumpuk-numpuk harta, surat al-Ma'un menerangkan kewajiban terhadap fakir miskin dan anak yatim serta pandangan agama tentang hidup bermasyarakat dan saling tolongmenolong. ${ }^{12}$ Periode pertama turunnya wahyu ini menimbulkan bermacammacam reaksi di kalangan masyarakat Arab, di antaranya: pertama, Sebagian kecil dari mereka menerima dengan baik dakwah dan ajakan Nabi. Kedua, Sebagian besar dari mereka menolak dakwah Nabi karena Jahiliyaannya ${ }^{13}$ dan lebih mempertahankan tradisi nenek moyang. ${ }^{14}$

\section{Periode kedua turunnya wahyu berlangsung selama delapan sampai sembilan tahun di Makkah.}

Pada periode kedua ini gerakan Jahiliyah yang tidak senang dengan datangnya Islam menggunakan berbagai macam cara untuk menghalangi dakwah Nabi. Baik dari segi Intimidasi, fitnah dan penganiayaan yang menyebabkan Nabi, sahabat dan para pengikutnya hijrah ke Habsyah kemudian ke Madinah. Pada periode kedua ini ayat alQuran turun dengan memberikan keterangan atas kewajiban-kewajiban dasar sesuai dengan keadaan yang terjadi, di antaranya ialah:

a. Seruan untuk berdakwah: "Ajaklah mereka ke jalan Tuhanmu dengan cara yang baik dan bantahlah mereka dengan jalan yang baik pula, karena sesunggunya hanya Allah yang mengetahui siapa yang sesat dan Allah juga lebih mengetahui siapa yang mendapat petunjuk". ${ }^{15}$

\footnotetext{
${ }^{12}$ M. Quraish Shihab, Membumikan al-Qur'an, (Bandung: Mizan, 1999), 36.

${ }^{13}$ QS. Al-Anbiya ayat 24.

${ }^{14}$ QS. Az-Zukhruf ayat 22.

${ }^{15}$ QS. An-Nahl ayat 125.
} 
b. Ancaman bagi kaum musyrik: "Apabila mereka mendurhakai Allah dan berpaling dari kebenaran, niscaya Allah akan masukkan mereka ke dalam api neraka dan kekal di dalamnya". 16

c. Tentang keesaan Allah: "Manusia memberikan perumpamaan bagi kami dan melupakan asal kejadiannya, merekapun berkata: "Siapakah yang mampu menghidupkan tulang-tulang yang telah hancur?" Katakanlah wahai Muhammad: "Yang akan menghidupkan ialah Allah yang menjadikanna pertama kali”. Wahai manusia, Tuhan telah menjadikan api dari kayu yang basah lalu dengan kayu itu kamu menyalakannya. Tidaklah yang menciptakan langit dan bumi sanggup menciptakan yang serupa itu? Sesungguhnya Allah maha pencipta dan maha mengetahui. Apabila Allah menghendaki sesuatu, maka Ia hanya memerintahkan: “Jadilah! Maka jadilah ia". ${ }^{17}$

Turunnya wahyu pada periode Makkah lebih dominan berbicara masalah akhlak, perilaku sosial dalam bermasyarakat dan ayat-ayat tentang siksaan bagi yang tidak mempercayai keesaan Allah, ${ }^{18}$ walaupun pada periode Makkah banyak masyarakat yang menolak dan menentang dakwah Nabi.

\section{Periode ketiga turunnya wahyu al-Quran berlangsung di Madinah selama sepuluh tahun dan telah mendapatkan kebebasan bagi para pengikutnya untuk melaksanakan ajaran agama.}

Pada periode ketiga, al-Quran menurunkan ayat yang membangkitkan semangat Nabi dalam berdakwah, sebagaimana firman Allah: "Hendaklah kamu memerangi orang-orang yang mengingkari janjinya dan mengusir Nabi. Apakah kalian takut kepada mereka? Sesungguhnya Allah yang lebih berhak untuk ditakuti jika kalian benar-benar beriman. Perangilah! Allah akan menyiksa mereka, sesungguhnya Allah akan menerangi dan memuaskan hati golongan orang-orang yang beriman". ${ }^{19}$ Allah juga menurunkan ayat tentang peringatan yang harus dihindari, sebagaimana firman Allah:

\footnotetext{
${ }^{16}$ QS. An-Nisa ayat 14.

${ }^{17}$ QS. Yasiin ayat 78-82.

18 Amir Mahmud, Fase Turunnya al-Qur'an Dan Urgensitasnya, Mafhum, vol. 1, no. 1, (Mei 2016), hlm. 016.

${ }^{19}$ QS. At-Taubah ayat 13-14.
} 
"Wahai orang-orang yang beriman, sesungguhnya minuman keras, perjudian, berhala dan bertenung adalah perbuatan-perbuatan setan. Oleh karena itu, hindarilah semua itu agar kamu sekalian mendapat kemenangan. Sesunguhnya setan menginginkan permusuhan di antara kamu dan memalingkan kamu untuk mengingat Allah, maka hentikanlah perbuatan-perbuatan tersebut". ${ }^{20}$

Pada periode Madinah, wahyu turun membicarakan tentang aturan berupa hak dan kewajiban, masalah ekonomi, hubungan masyarakat, kriminal dan lain sebagainya. Penduduk Madinah lebih terbuka dan menerima dengan baik apa yang Nabi sampaikan, berbeda dengan penduduk Makkah yang mayoritas penduduknya masih ortodok dan lebih memilih mempertahankan warisan adat istiadat nenek moyang. Di sinilah tujuan Allah menurunkan wahyu secara bertahap karena melihat kondisi masyarakat yang dihadapi Nabi dalam berdakwah, implikasi yang diharapkan dari cara dakwah secara bertahap adalah agar masyarakat dapat menerimanya dengan baik dan tidak terbebani karena pemberlakuannya sedikit demi sedikit. Dari segi masa turunnya, ayat atau surat Makkiyah dan Madaniyah dapat dibedakan menjadi tiga:

1. Dari segi waktu turunnya. Makkiyah adalah wahyu yang diturunkan sebelum Nabi hijrah meskipun bukan di Mekkah. Sedangkan Madaniyah adalah wahyu yang diturunkan sesudah Nabi hijrah mesipun Nabi berada di Mekkah dan Arafah. Sebagaimana wahyu yang diturunkan pada tahun penaklukan kota Mekah, yaitu surat an-Nisa ayat 58 .

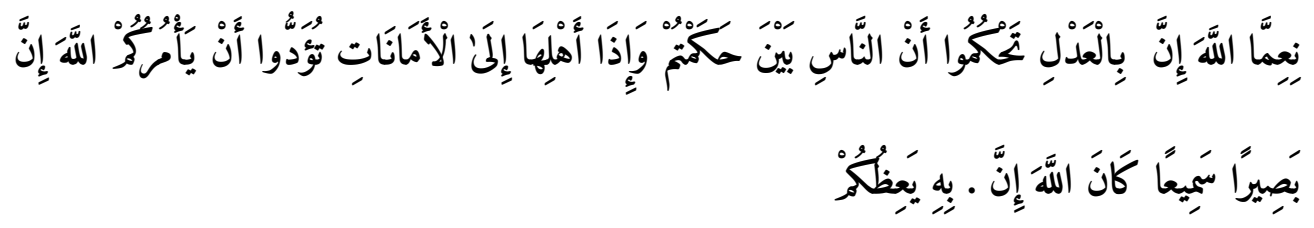

Artinya: Sesungguhnya Allah memerintahkan agar kamu menyampaikan amanah kepada orang yang berhak menerimanya, apabila kamu menetapkan suatu hukum, maka tetapkanlah dengan seadil-adilnya. Sesungguhnya Allah memberimu pengajaran yang baik. Sesungguhnya Allah maha mendengar dan maha melihat. ${ }^{21}$

\footnotetext{
${ }^{20}$ QS. Al-Maidah ayat 90-91.

${ }^{21}$ QS. An-Nisa ayat 58.
} 
Diturunkan pada haji wada' seperti firman Allah dalam surat al-Maidah ayat $3 .^{22}$

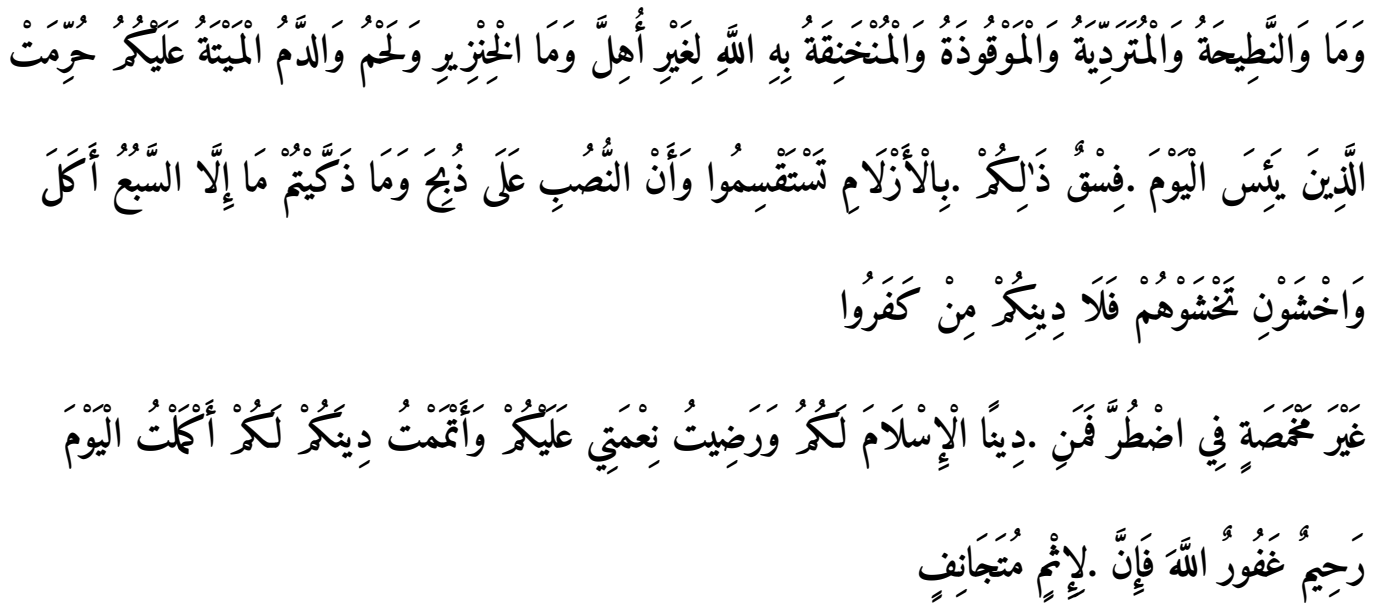

Artinya: "Diharamkan bagimu memakan bangkai, darah, daging babi, hewan yang disembelih dengan tidak menyebut nama Allah, hewan yang tercekik, terpukul, jatuh, ditanduk dan diterkam binatang buas kecuali yang sempat disembelih. Diharamkan memakan hewan yang disembelih untuk berhala. Diharamkan mengundi nasib dengan anak panah, karena hal yang demikian itu perbuatan fasik. Pada hari ini orang-orang kafir telah putus asa untuk mengalahkan agamamu, janganlah kamu takut kepada mereka, akan tetapi takutlah kamu kepada Allah. Pada hari ini telah aku sempurnakan agama untukmu, telah aku cukupkan nikmat bagimu dan telah aku ridhoi Islam sebagai agamamu. Barangsiapa melakukan sesuatu karena lapar dan bukan karena berbuat dosa, maka sesungguhnya Allah maha pengampun lagi maha penyayang". ${ }^{23}$

2. Dari segi tempat turunnya. Makkiyah adalah wahyu yang turun di Makkah dan sekitarnya. Seperti Mina, Arafah dan Hudaibiyah. Madaniyah adalah wahyu yang turun di Madinah dan sekitarnya. Seperti Uhud, Quba dan Sil.

3. Dari segi sasarannya. Makkiyah adalah ayat yang seruannya ditujukan kepada penduduk Mekkah. Madaniyah adalah ayat yang seruannya ditujukan kepada penduduk Madinah. Ayat al-Quran yang mengandung seruan ya ayyuhannas (wahai manusia) adalah Makkiyah. Sedangkan ayat al-Quran yang mengandung seruan ya ayyuhal lajina amanu (hai orang-orang yang beriman) adalah

\footnotetext{
${ }^{22}$ Dalam hadits shahih dari Umar dijelaskan, bahwa ayat itu turun pada malam Arafah hari jumat tahun haji wada'.

${ }^{23}$ QS. Al-Maidah ayat 3.
} 
Madaniyah. Di samping itu, ada surat Madaniyah yang dibuka dengan seruan ya ayyuhan nas. Sebagaimana dalam surat al-Baqarah ayat 21.

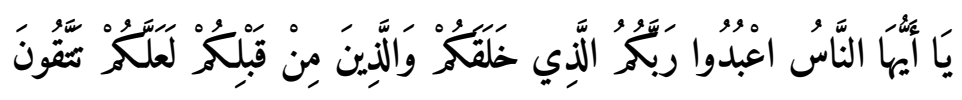

Artinya: "Wahai manusia! Sembahlah Tuhanmu yang telah menciptakanmu dan orang-orang yang sebelum kamu, mudah-mudahan kamu termasuk orang-orang yang bertakwa." 24

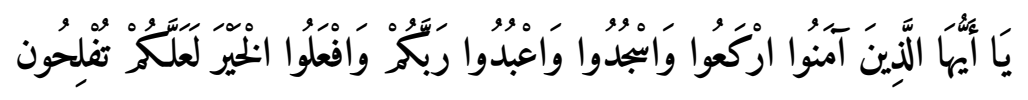

Artinya: "Wahai orang-orang yang beriman! Rukuklah, sujudlah, sembahlah Tuhanmu dan berbuatlah kebaikan agar kamu beruntung". ${ }^{25}$

\section{Ciri-ciri ayat atau surat Makkiyah dan Madaniyah:}

Ciri-ciri surat Makkiyah ialah pertama, mengandung ayat-ayat sajadah, kedua mengandung lafadz kalla. Ketiga dimulai dengan redaksi ya ayyuhan nas kecuali surat al-Hajj ayat $77 .^{26}$ Keempat mengandung kisah para Nabi dan umat terdahulu. Kelima, mengandung kisah Nabi Adam dan Iblis kecuali al-Baqarah ayat 2. Keenam, dibuka dengan muqattha'ah atau hija'I. Ketujuh, mengandung tauhid dan beribadah hanya kepada Allah. ${ }^{27}$ Kedelapan, ayat dan suratnya pendek, nada serta perkataannya keras dan kesembilan ialah banyak mengandung kata-kata sumpah.

Sedangkan Ciri-ciri surat Madaniyah ialah pertama, mengandung ketentuanketentuan faraid dan had. Kedua, mengandung sindiran terhadap kaum munafik kecuali surat al-Ankabut ayat 29. Ketiga, meng-khitabi ${ }^{28}$ ahli kitab dan menguraikan perbuatan mereka yang telah menyimpang dari kitab Allah. Keempat, mengungkap langkahlangkah orang munafik. Kelima, Surat dan sebagian ayatnya panjang dan keenam adalah menjelaskan hukum dan menggunakan uslub dengan jelas.

\footnotetext{
${ }^{24}$ QS. Al-Baqarah ayat 21.

${ }^{25}$ QS. Al-Hajj ayat 77. Al-hajj ayat 77 adalah surat Madaniyah akan tetapi sebagian besar ulama mengatakan bahwa surat al-Hajj ayat 77 ini adalah surat Makkiyah.

${ }^{26}$ Di awali dengan ya ayyuhal lajina атапu, sebagian besar ulama berpendapat bahwa ayat tersebut adalah Makkiyah

${ }^{27}$ Rosihon Anwar, Ulumul Quran, cet. ke-4, (Bandung: CV Pustaka Setia), hlm. 107.

${ }^{28}$ Khitabi ialah gaya bahasa al-Quran untuk mengajak orang-orang kafir untuk masuk Islam.
} 


\section{TARTIB MUSHAFI}

Dalam penyusunan dan runtunan surat pada al-Quran, para ulama berbeda pandangan atau pendapat diantaranya sebagai berikut:

1. Kelompok pertama, sebagian ulama berpendapat bahwa penyusunan urutan surat dalam al-Quran berdasarkan pada ijtihad sahabat. Pendapat ini dinisbatkan kepada jumhur ulama dengan beberapa alasan:

a. Berbedanya tartib mushaf pada tulisan para sahabat sebelum dikodifikasi

1) Ubay bin Ka'ab susunan mushaf-nya diawali dengan surat al-Fatihah, alBaqarah kemudian an-Nisa

2) Ibn Mas'ud susunan mushaf-nya diawali dengan surat al-Baqarah, an-Nisa dan Ali Imran

3) Ali susunan mushafnya dimulai dengan surat al-'Ala, al-Mudatsir dan alMuzammil

Atas dasar mushaf sahabat inilah para ulama berpandangan bahwa seandainya mushaf dalam al-Quran bersifat tauqifi tentu para sahabat tidak berbeda penyusunan dalam mushaf-nya.

\section{Adanya riwayat Ibnu Abbas}

Dari Yazid al-Farisi ia berkata: Aku telah mendengar Ibnu Abbas berkata: Aku bertanya kepada Usman bin Affan: Apakah alasanmu meletakkan surat Bara'ah yang termasuk al-main dan surat al-Anfal termasuk al-matsani pada sab'u ath-thiwal dan tidak engkau tuliskan bismillahirahmanirrahim antara keduanya. Usman menjawab: Ketika turun beberapa ayat, Nabi memanggil para penulis wahyu dan berkata: "Letakkan ayat ini pada surat yang menyebutkan di dalamnya tentang ini dan ini". Ketika turun satu atau dua ayat, Nabi memerintahkan seperti demikian. Al-anfal adalah surat pertama dan Bara'ah adalah surat terakhir yang diturunkan di Madinah. Kisah pada surat al-Anfal mirip dengan kisah pada surat Bara'ah, sehingga aku mengira surat Bara'ah adalah bagian dari surat al-Anfal, karena itu aku tidak tuliskan di antara keduanya bismillahirrahmanirrahim dan aku letakkan pada as-sab'u ath-thiwal (Kutubuttis'ah : Abu daud : no. 786). 
Atas dasar riwayat Ibnu Abbas inilah para ulama berpendapat bahwa Usman ber-ijtihad dalam penyusunan tartib mushaf.

3. Kelompok kedua, sebagian ulama yang lain sepakat bahwa penyusunan urutan surat dalam al-Quran bersifat tauqifi sebagaimana tauqifi-nya tartib ayat. Pendapat ini dinisbahkan kepada Abu Bakar al-Anbari, at-Thibiy dan Abu Ja'far an-Nuhas dengan alasan:

a. Surat-surat yang mempunyai kemiripan isinya tidak disusun secara berurutan dalam mushaf, seperti surat yang dibuka dengan musabbihat yang diselingi dengan surat lain. Surat al-Hasyar dan surat as-Shafat diselingi dengan surat al-Mumtahanah, surat Taghabun dan surat al-Jumuah diselingi dengan surat al-Munafiqun.

b. Tidak ada sahabat yang keberatan atas tartib mushafi yang disusun Usman Ibn Affan

c. Dalam riwayat Ibnu Abi Syaibah mengatakan bahwa Nabi telah membaca beberapa surat dalam shalat secara berurutan.

4. Kelompok ketiga berpendapat bahwa susunan surat dalam al-Quran bersifat tauqifi. Pandangan ini berdasarkan pada riwayat-riwayat yang menerangkan ke tauqifi-nya. Seperti as-Sab'u at-Thiwal, al-Hawamim dan Mufasshal. Selain ketentuan dari Nabi, maka susunan dan urutan surat dalam mushaf al-Quran bersifat ijtihadi. ${ }^{29}$

Perbedaan pendapat dari ketiga kelompok ini memiliki argumentasi yang berbeda dan beragam. Namun, mayoritas ulama lebih berpegang kepada pendapat yang kedua dibandingkan dengan pendapat kelompok kesatu dan ketiga. Dengan beberapa alasan:

1. Para sahabat memiliki mushaf masing-masing dan berbeda dengan tartib mushafi yang disusun oleh Usman Ibn Affan disebabkan turunnya al-Quran belum lengkap sehingga para sahabat menulis mushaf sesuai dengan apa yang mereka dengar dan terima dari Nabi.

${ }^{29}$ Yulia Rahmi, Penetapan Susunan Ayat, Surat Dan Rasm Al-quran, JURNAL ULUNNUHA, Volume 6, Nomor 2, (Desember 2017), hlm.189-191. Lihat juga Manna Al-qaththan, Mabahis fi Ulumil Quran, cet. ke-13, (Kairo: Maktabah Wahbah), hlm. 357. 
2. Para sahabat menulis mushaf dan tartib surat hanya untuk kepentingan pribadi agar lebih mudah menghafalnya.

3. Tartib surat yang disusun Khalifah Usman bersifat tauqifi atas petunjuk dari Nabi langsung sehingga para sahabat sepakat dan menerima bahkan mereka rela membakar dan meninggalkan mushaf yang mereka tulis.

Allah menurunkan wahyu dengan beraneka ragam cara Nabi menerimanya, di antara peristiwa tersebut adalah wahyu datang dengan gemuruh suara bunyi lonceng, badan Nabi merasa kedinginan hingga berkeringat, Malaikat Jibril datang dengan jelmaan manusia. ${ }^{30}$ Setiap ayat al-Quran turun, Nabi langsung mendiktekan kepada sahabat untuk menghafal, memerintahkan menulis dan menunjukkan secara langsung tempat ayat tersebut ke dalam susunan surat al-Quran. Nabi Muhammad selalu meminta para sahabat mengulang hafalannya agar tidak terjadi kesalahan dalam pelafalan bacaan dan susunan ayatnya. Setiap bulan Ramadhan Malaikat Jibril datang kepada Nabi dan satu tahun sebelum Nabi wafat Malaikat Jibril datang dua kali untuk mendengarkan bacaan ayat-ayat al-Quran.

\section{A. Kodifikasi pada masa Nabi}

Pada masa Nabi al-Quran dikumpulkan dengan dua cara: Pertama, pengumpulan al-Quran dengan hafalan. Nabi orang yang pertama menghafal ketika wahyu turun, kemudian menyampaikannya kepada sahabat, para sahabat diperintahkan Nabi untuk menghafalnya dan menyampaikan kepada keluarga dan para sahabat lainnya. Pada saat penerimaan wahyu Nabi sangat bersemangat untuk menghafalnya, suatu ketika Malaikat Jibril datang dan belum selesai menyampaikan wahyu, Nabi terlihat menggerakkan bibir dan lidahnya sebagai upaya keras untuk menghafalnya. Dari kejadian ini, Allah langsung menurunkan ayat: "Janganlah kamu menggerakkan lidahmu untuk cepat-cepat menghafal. Sesungguhnya atas kuasa kamilah mengumpulkan di dadamu dan membuatmu mudah menghafalnya. Apabila kami telah selesai membacakan, lalu ikutilah bacaan itu. Sesungguhnya atas tanggungan kamilah penjelasannya". ${ }^{31}$ Kedua, pengumpulan al-Quran dengan tulisan. Apabila wahyu turun, Nabi langsung

30 Yusron Masduki, Sejarah Turunnya Al-quran Penuh Fenomenal (Muatan Nilai-nilai Psikologis Dalam Pendidikan), Medina-Te, Vol. 16, No. 1, (Juni 2017), hlm. 43.

${ }^{31}$ QS. Al-Qiyamah ayat (16-19). 
memerintahkan sahabat untuk menulisnya dan menunjukkan letak ayat atau surat dalam al-Quran.

\section{B. Kodifikasi pada masa Abu Bakar}

Pada masa Abu Bakar menjadi Khalifah, banyak terjadi peristiwa-peristiwa besar yang mengakibatkan para sahabat penghafal al-Quran banyak yang gugur dalam peperangan. Atas peristiwa inilah kemudian Umar Ibn Khatab merasa khawatir dan mengusulkan kepada Abu Bakar untuk segera mengumpulkan al-Quran dan ditulis dalam satu kitab. Pada mulanya Abu Bakar merasa ragu atas usulan Umar Ibn Khatab, karena Nabi tidak pernah memerintahkan sahabat untuk mengumpulkan al-Quran, sehingga Allah membukakan hati Abu Bakar untuk menerima gagasan Umar tersebut mengingat akan manfaat dan kebaikannya di kemudian hari. Abu Bakar memerintahkan Zaid bin Sabit karena kemampuan dan kualitas hafalannya yang mumpuni dari segi bacaan, tulisan dan pemahamannya tentang al-Quran. Dalam pengumpulannya, Zaid bin Sabit bersandar pada hafalan ahli qurra dan catatan yang disimpan para sahabat melalui proses seleksi yang sangat teliti dan cermat. $^{32}$

Dalam pengumpulan al-Quran Abu Bakar menetapkan syarat yang ketat dengan memberikan intruksi kepada sahabat: "Apabila ada yang datang membawa sesuatu dari al-Quran dan disertai dengan dua orang saksi, maka catatlah". ${ }^{33}$ Menurut para ulama syarat mendatangkan dua orang saksi dalam pencatatan al-Quran mengandung arti. Pertama, orang yang kuat hafalannya dan mempunyai catatan. Kedua, dua orang yang menyaksikan langsung bahwa ayat tersebut dicatat di hadapan Nabi. Ketiga, dua orang saksi tersebut siap disumpah bahwa catatan tersebut telah disahkan oleh Nabi. ${ }^{34}$ Pada masa Umar Ibn Khatab mushaf dari Abu Bakar disalin kembali dalam bentuk shahifah yang lebih baik. Setelah proses penulisan

\footnotetext{
32 Ismail, Sistematika Mushaf Al-Qur'an, TA'DIBIA Jurnal Ilmiah Pendidikan Agama Islam, Vol. 8 No. 1 (Mei 2018), hlm. 89. H), hlm. 14.

${ }^{33}$ Ibn Hajar Al-asqalani, Fath al-Barri, Jilid 9, (Kairo: al-Matba'ajh al-Salafiyyah, 1380-1390

${ }^{34}$ Syamsuddin Arif, Tekstualisasi al-Qur'an: Antara Kenyataan dan Kesalahpahaman, Jurnal TSAQAFAH, Vol. 12, No. 2, (November 2016), hlm. 334.
} 
selesai, mushaf tersebut diserahkan kepada Hafshah selaku istri Nabi untuk disimpan. $^{35}$

\section{Kodifikasi pada masa Usman Ibn Affan}

Pada masa Usman Ibn Affan Islam mulai tersebar luas ke berbagai penjuru, sehingga orang-orang yang baru masuk Islam ingin mempelajari al-Quran sebagai sumber pedoman hidup. Akan tetapi, qiraah yang diajarkan para sahabat ketika itu berlainan satu sama lain yang membuat Khalifah Usman Ibn Affan khawatir akan terjadi penyalahgunaan dalam bacaan dan tulisan. Atas peristiwa yang terjadi, Khalifah Utsman ibn Affan membentuk panitia untuk melakukan pembukuan besar, mushaf yang ditulis Abu Bakar kemudian dijadikan satu kitab berdasarkan tartib mushafi dalam rasm utsmani yang hingga saat ini dijadikan standar baku dalam penulisan al-Quran. ${ }^{36}$ Ayat pertama turun adalah lima ayat pertama dari surat al-Alaq yang diletakkan pada urutan 96 dan surat al-Fatihah diletakkan pada urutan pertama sebagai pembuka surat dalam mushaf utsmani, pada akhirnya Usman Ibn Affan memerintahkan kepada para sahabat untuk memusnahkan mushaf yang berbeda.

Model penyusunan tartib mushafi rasm utsmani inilah yang dijadikan patokan dan urutan bagi mufasir dalam menulis karya tafsirnya. Beberapa tafsir yang disusun berdasarkan tartib mushafi adalah: Tafsir al-Manar karya Muhammad Abduh, Tafsir Jami’ li al-Ahkam al-Quran karya al-Qurtubi, Tafsir al-Misbah karya M. Quraish Shihab. Di samping itu, ada beberapa mufasir yang menyusun kitab tafsirnya dengan sistematika tartib nuzuli, di antaranya: Fahm al-Quran al-Hakim al-Tafsir al-Wadih Tartib an-Nuzul karya M. Abid al-Jabiri, Al-Tafsir al-Hadits Tartib al-Suwar Hasba al-Nuzul karya Izzat Darwajah dan Tafsir al-Bayani li al-Quran al-Karim karya Aisyah Abdurrahman binti Syati.

Darwajah adalah seorang mufasir kontemporer melakukan penafsiran dengan metode tartib nuzuli yang bersumber dari penafsiran ra'yi dan atsar, tujuan utamanya

\footnotetext{
${ }^{35}$ Amri, Autentisitas Dan Gradualitas Al-Quran, Jurnal Substantia, Vol. 15, No. 2, (Oktober 2013), hlm. 170.

${ }^{36}$ Utsman bin Abi Ash mengatakan: Bahwa nabi selalu memanggil penulisnya dan berkata: "Letakkanlah ayat-ayat tersebut ke dalam suarah yang beliau sebut". Utsman melaporkan bahwa saat sedang duduk bersama nabi, ketika memalingkan pandangan pada satu titik kemudian berkata: "Malaikat Jibril menemuiku dan meminta agar ayat ini (An-nahl 16:90) diletakkan pada bagian surah tertentu". Dalam Ahmad bin Muhammad bin Hanbal, Musnad Imam Ahmad bin Hambal (Kairo: Dar al-Hadits, 1996), hlm. 218.
} 
ialah untuk memproduksi penafsiran yang realistis dan merefleksikan teks dengan pedekatan keilmuan yang sesuai dengan perkembangan zaman. Tafsir klasik disebut sebagai tafsir era afirmatif yang bernalar ideologis dan setelahnya muncul karyakarya tafsir yang bernalar dinamis dan dialogis. ${ }^{37}$ Teks didudukkan sebagai ilmu pengetahuan dan bagaimana ilmu pengetahuan itu dapat dikembangkan melalui penafsiran. Sebuah karya baik metode maupun penafsiran dapat dinilai berdasarkan kedekatan teks secara empiris sesuai dengan fakta yang melikupinya dan berdasarkan usaha penafsir dalam menemukan makna, hukum dan fungsi dari penafsiran.

Tartib adalah isim masdar dari kata rataba yang mengandung arti urutan atau aturan. ${ }^{38}$ Kata nuzul diartikan dengan turun, apabila dikaitkan dengan kata al-Quran maka bermakna susunan al-Quran berdasarkan dengan urutan turunnya wahyu dari Allah kepada Nabi Muhammad SAW. Sedangkan tartib mushafi adalah susunan ayat dan surat al-Quran bersifat tauqifi yang mempertimbangkan peristiwa dan proses turunnya wahyu sesuai dengan petunjuk dan arahan Nabi. Susunan al-Quran tidak berdasarkan urutan turunnya, akan tetapi Nabi langsung menetapkan dan meletakkan wahyu yang baru diterimanya pada suatu surat, susunan ayat dan surat inilah kemudian pada masa Khalifah Utsman ibn Affan dikodifikasi menjadi mushaf utsmani. $^{39}$

Tafsir nuzuli adalah metode untuk memahami ayat-ayat al-Quran dengan cara mengurutkan susunan kronologis turunnya ayat. Oleh karena itu, penafsiran secara tartib nuzuli lebih terfokus pada al-Quran yang disusun secara nuzuli dengan melihat riwayat-riwayat yang melatarbelakangi turunnya ayat. Dengan demikian, tafsir nuzuli sangat berbeda dengan tafsir mushafi yang terfokus pada mushaf al-Quran yang telah diurutkan susunan ayat dan suratnya sejak zaman Nabi. Hal ini yang menjadi alasan para ahli tafsir dan jarang menafsirkan al-Quran dengan tartib nuzuli karena dianggap tidak sesuai dengan tartib mushafi. ${ }^{40}$ Tartib nuzuli dapat dibedakan menjadi dua macam: Pertama, Tartib secara umum, yaitu mengelompokkan surat

${ }^{37}$ Abdul Mustaqim, Epistimologi Tafsir Kontemporer, (Yogyakarta: LKIS Group, 2012), hlm. $35-84$.

${ }^{38}$ Husin Al-Habsy, Kamus Al-kautsar Arab Indonesia, (Surabaya: Darussagaf PP), hlm. 122.

39 Abu Anwar, Keharmonisan Sistematika Al-quran (Kajian terhadap Munasabah dalam alQur'an), Al-Fikra: Jurnal Ilmiah Keislaman, Vol. 7, No. 1, (Januari-Juni 2008), hlm. 20.

${ }^{40}$ Fatimah al Zahrah, Memahami Tafsir Nuzuli Al-quran (Studi atas Buku Tafsir al-Qur'an alKarim: Tafsir atas Surat-surat Pendek Berdasarkan Urutan Turunnya Wahyu Karya M. Quraish Shihab), Jurnal KACA Jurusan Ushuluddin STAI AL FITHRAH, Volume 10, Nomor 2, (Agustus 2020), hlm. 165. 
Makkiyah sebelum surat Madaniyah dan penyusunannya tidak berurutan. Kedua, Tartib secara khusus, yaitu mengurutkan surat al-Quran dari yang pertama turun hingga yang terakhir.

Dari penjelasan sejarah dan para sahabat terdahulu, bahwa pada masa Nabi susunan ayat dan surat dalam al-Quran sudah baku yang bersifat tauqifi bukan ijtihadi. Para ulama juga sepakat bahwa penyusunan ayat-ayat al-Quran bersifat tauqifi, berdasarkan petunjuk Nabi langsung dan tidak ada peran ijtihad para sahabat. Malaikat Jibril membacakan ayat-ayat tersebut dan memberi bimbingan langsung kepada Nabi Muhammad letak ayat dalam suratnya, kemudian Nabi membacakan kepada sahabat dan memerintahkan untuk menulisnya sehingga Nabi menjelaskan "letakkan ayat-ayat ini pada surat ini sesudah ayat ini atau sebelum ayat ini". ${ }^{41}$ Nabi membacakan ayat-ayat tersebut berulang-ulang sebagai pelajaran maupun nasihat kepada sahabat, baik di waktu shalat, berkhutbah maupun dalam kesempatan yang lain.

Berbagai permasalahan kontemporer yang dihadapi saat ini, al-Quran dan hadits $^{42}$ dituntut untuk berbicara, mengomentari dan memutuskan terhadap permasalahan yang muncul, baik untuk menyalahkan, membenarkan, membiarkan bahkan menolaknya. ${ }^{43}$ Ketika ayat al-Quran turun, banyak dari kalangan sahabat yang belum memahaminya, sehingga bisa bertanya dan meminta penjelasan langsung kepada Nabi Muhammad, setelah Nabi wafat, para sahabat yang belum memahami isi kandungan al-Quran dapat bertanya kepada sahabat ${ }^{44}$ yang paling dekat kepada Nabi. Untuk mendapatkan pemaknaan yang tepat dari al-Quran perlu mempelajari asbabun nuzul dari sebuah ayat agar penjelasan konteks historis yang melatarbelakanginya dapat dipahami secara keseluruhan. Dari pemahaman kontekstual inilah yang kemudian

41 Al-Hafizh Jalal Ad-din Abd Ar-rahman As-suyuthi, Al-itqan fi Ulum Al-quran, ,jilid 1, (Beirut : Al-maktabah Al-ashriyyah), hlm. 189. Hadits dikeluarkan Imam Ahmad dari rowayat Ibn Abbas, dari Usman bin Affan.

42 Al-quran dan Hadits adalah dalil pokok yang keberadaannya tidak memerlukan dalil lain (Pengertian ini lebih merujuk kepada arti masadir atau sumber hukum). Ali Sidikin, Fiqh Ushul Fiqh (Sejarah, Metodologi dan Implementasinya di Indonesia), cet. ke-1, (Yogyakarta: Penerbit Beranda Publising), hlm. 65.

43 Duwi Harono, Hadits Dalam Fatwa Dan Permasalahan Sosial Kontemporer (Analisis Pemahaman Hadits MUI Dalam Keputusan Ijtima' Ulama Komisi Fatwa Seindonesia III Di Padang Panjang Tahun 2009, Tesis UIN Sunan Kalijaga Yogyakarta 2010, hlm. 2.

${ }^{44}$ Seperti Ibn Abbas yang pernah didoakan Nabi agar diberi pengetahuan untuk memahami alQuran. 
membantu umat Islam untuk merelevansikan kandungan al-Quran dalam kehidupan modern. ${ }^{45}$

Pemahaman al-Quran dengan menggunakan asbabun nuzuli dapat mempelajari kaitan logis proses turunnya wahyu dengan sejarah perjalanan dakwah $\mathrm{Nabi}^{46}$ dan dapat membantu dalam penerapan hukumnya baik secara historis maupun sosiologis. Para ulama dalam menghadapi suatu masalah, penetapannya dengan kaidah dan aturan yang dihasilkan melalui analisa sebagai terobosan untuk mencari jalan keluar dalam menetapkan hukum. Turunnya ayat al-Quran yang didahului dengan asbabun nuzul dapat menjadi patokan dalam memahami redaksinya yang bersifat umum terhadap pelaku yang menjadi sebab. Kekhususan sebab dan keumuman lafal berarti sebab menjadi khusus daripada jawaban dan jawaban lebih umum daripada sebab. Sebab adalah pertanyaan atau peristiwa yang melatarbelakangi turunnya ayat, sedangkan jawaban adalah ayat al-Quran yang diturunkan sebagai tanggapan dari pertanyaan atau peristiwa yang dihadapi Nabi dan para sahabat. ${ }^{47}$

Idealnya ketika mempelajari al-Quran adalah dengan memahami asbabun nuzul dan ilmu munasabah al-Quran untuk mengungkap pengertian ayat dari dasar urutan mushaf yang sesuai dengan peristiwa perjalanan dakwah Nabi, karena susunan ayat dan surat secara tauqifi masih mengandung permasalahan dan diskusi panjang dalam menyelesaikan rahasia yang terkandung di dalamnya.

\section{KESIMPULAN}

Al-Quran diturunkan secara berangsur-angsur bertujuan agar dapat memberikan pengajaran bagi penganutnya dan hukum yang terkandung di dalamnya merupakan satu kesatuan yang tidak dapat dipisahkan, hal ini menunjukkan bahwa al-Quran sebagai kitab penyempurna dan pembeda dari kitab-kitab suci sebelumnya. Al-Quran turun sekaligus dari lauh al-Mahfuz ke lauh al-Izza dan dari lauh al-Izza diturunkan secara berangsur-angsur kepada Nabi Muhammad melalui periode Makkah yang disebut

\footnotetext{
${ }^{45}$ Ali Sidikin, Fiqh Ushul Fiqh (Sejarah, Metodologi dan Implementasinya di Indonesia), cet. ke-1, (Yogyakarta: Penerbit Beranda Publising), hlm. 70.

${ }^{46}$ Aksin Wijaya, Sejarah Kenabian Dalam Perspektif Tafsir Nuzuli M. Izzat Darwazah, (Bandung: Mizan), hlm. 52

${ }^{47}$ Usman, Ulumul Quran, cet. ke-1, (Yogyakarta: Sukses Offset), hlm. 148.
} 
dengan ayat-ayat Makkiyah dan periode Madinah yang disebut dengan ayat-ayat Madaniyah.

Landasan utama dalam penyusunan al-Quran adalah: Pertama, susunan dan urutan ayat atau surat dalam al-Quran memiliki sistematika tauqifi, berdasarkan petunjuk Nabi sesuai dengan wahyu Allah. Kedua, al-Quran sebagai mu'jizat Nabi Muhammad yang memiliki kandungan nilai universal dan saling terkait secara utuh dalam satu kesatuan.

\section{DAFTAR PUSTAKA}

Abdul Mustaqim, Epistimologi Tafsir Kontemporer, Yogyakarta: LKIS Group, 2012.

Al-qaththan, Manna, Mabahits Fi Ulumil Quran (Dasar-dasar Ilmu Al-quran), cet. ke1, Jakarta: Ummul Qura, 2018.

Anwar, Rosihon, Samudra Al-quran, cet. ke-1, Bandung: Pustaka Setia, 2001.

Anwar, Rosihon, Ulumul Quran, cet. ke-4, Bandung: CV Pustaka Setia, 2013.

As-suyuthi, Al-Hafizh Jalal Ad-din Abd Ar-rahman, Al-itqan fi Ulum Al-quran, , jilid 1, Beirut : Al-maktabah Al-ashiriyyah.

El-Mazni, H. Anuar Rafiq, Pengantar Studi Ilmu Al-quran, cet. ke-2, Jakarta: Pustaka Al-Kautsar, 2007.

Ibn Hajar Al-asqalani, Fath al-Barri, Jilid 9, (Kairo: al-Matba'ajh al-Salafiyyah, 1380$1390 \mathrm{H})$

Sidikin, Ali, Fiqh Ushul Fiqh (Sejarah, Metodologi dan Implementasinya di Indonesia), cet. ke-1, Yogyakarta: Penerbit Beranda Publising, 2012.

Shihab, M. Quraish, Membumikan al-Qur'an, Bandung: Mizan, 1999.

Usman, Ulumul Quran, cet. ke-1, Yogyakarta: Sukses Offset, 2009.

Wijaya, Aksin, Sejarah Kenabian Dalam Perspektif Tafsir Nuzuli M. Izzat Darwazah, Bandung: Mizan, 2016.

Abu Anwar, Keharmonisan Sistematika Al-quran (Kajian terhadap Munasabah dalam al-Qur'an), Al-Fikra: Jurnal Ilmiah Keislaman, Vol. 7, No. 1, (Januari-Juni 2008). 
Al-Habsy, Husin, Kamus Al-kautsar Arab Indonesia, Surabaya: Darussagaf PP, 1997.

Al Zahrah, Fatimah, Memahami Tafsir Nuzuli Al-quran (Studi atas Buku Tafsir alQur'an al-Karim: Tafsir atas Surat-surat Pendek Berdasarkan Urutan Turunnya Wahyu Karya M. Quraish Shihab), Jurnal KACA, Volume 10, Nomor 2, (Agustus 2020).

Amin, Muhammad, Sistematika Turunnya Ayat-ayat Al-quran Sebagai Pola Gerakan Dakwah, Communica, Vol 2, No. 02, (Oktober 2004).

Amri, Autentisitas Dan Gradualitas Al-Quran, Jurnal Substantia, Vol. 15, No. 2, (Oktober 2013).

Arif, Syamsuddin, Tekstualisasi al-Qur'an: Antara Kenyataan dan Kesalahpahaman, Jurnal TSAQAFAH, Vol. 12, No. 2, (November 2016).

Harono, Duwi, Hadits Dalam Fatwa Dan Permasalahan Sosial Kontemporer (Analisis Pemahaman Hadits MUI Dalam Keputusan Ijtima' Ulama Komisi Fatwa Seindonesia III Di Padang Panjang Tahun 2009, Tesis UIN Sunan Kalijaga Yogyakarta 2010

Ismail, Sistematika Mushaf Al-Qur'an, TA'DIBIA Jurnal Ilmiah Pendidikan Agama Islam, Vol. 8 No. 1 (Mei 2018).

Khaeroni, Cahaya, Sejarah Al-quran (Uraian Analitis, Kronologis, dan Naratif tentang Sejarah Kodifikasi Al-4XU.DQ), Jurnal Historia, Volume 5, Nomor 2, (Tahun 2017).

Mahmud, Amir Fase Turunnya al-Qur'an Dan Urgensitasnya, Mafhum, vol. 1, no. 1, (Mei 2016).

Masduki, Yusron, Sejarah Turunnya Al-quran Penuh Fenomenal (Muatan Nilai-nilai Psikologis Dalam Pendidikan), Medina-Te, Vol. 16, No. 1, (Juni 2017).

Rahmi, Yulia, Penetapan Susunan Ayat, Surat Dan Rasm Al-quran, JURNAL ULUNNUHA, Volume 6, Nomor 2, (Desember 2017).

Riyani, Irma, Menelusuri Latar Historis Turunnya Al-quran Dan Proses Pembentukan Tatanan Masyarakat Islam, Al-Bayan, Jurnal Studi Al-Qur'an dan Tafsir, Vol. 1, No. 1, (Juni 2016). 